\title{
A Study on Perception and Experience of Plastic Surgery in Students of Beauty High School
}

Eun Hee Jo ${ }^{1}$, Myung Sun Lee $2^{*}$

${ }^{1}$ Department of Beauty Medicine, Graduate School of Health and Medicine, Daejeon University, Daejeon, Korea

${ }^{2}$ Department of Beauty and Healthcare, Daejeon University, Daejeon, Korea

\author{
"Corresponding author: Myung Sun Lee, \\ Department of Beauty and Healthcare, \\ Daejeon 34520, Korea \\ Tel.: +8242 2802393 \\ Fax: +82 422802783 \\ Email: leesun1460@hanmail.net \\ Received March 2, 2016 \\ Revised June 11, 2016 \\ Accepted June 30, 2016 \\ Published September 30, 2016
} Daejeon University, 62 Daehak-ro, Dong-gu,

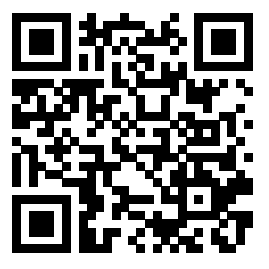

\begin{abstract}
Purpose: The goal of this study is to identify side effects level of plastic surgery by examining perception and experience on it through appearance satisfaction level in students of beauty high school. Methods: A questionnaire survey was conducted to students of beauty high school in Chungcheong area. The survey forms were distributed to 492 students in total, which were analyzed with SPSS ver. 21.0. The variables were measured by crossover analysis after multiple response processing. Results: The result showed that both appearance stress and plastic surgery experience in female students are more than in male students. After the plastic surgery, $45.8 \%$ of responders experienced side effects and most side effects were bruise and swelling. Conclusion: According to the survey above, most of the students in beauty high school underwent plastic surgery because of stress from unsatisfactory appearance. After the plastic surgery, their self-satisfaction and confidence were increased. However, many students had experience post-plastic surgery side effects because they were in the adolescence period for growing up.
\end{abstract}

Keywords: Cosmetic surgery, Beauty high school, Students, Perception, Experience

\section{Introduction}

현대 사회는 산업화가 진행되고, 점차 발전하면서 경쟁적 구도 를 가지게 되어 자신을 타인과 다르게 차별화시키고, 자기 자신만 의 개성과 매력을 더하기 위하여 외모에 대한 관심을 미적추구의 경쟁적 수단으로 인식하고 있다(Kim \& Nam, 2010). 우리나라는 세계 최고의 성형국가라는 오명과 함께 취업에도 외모를 중요시 하는 ‘외모 지상주의' 사회풍토가 팽배하면서, 현대 사회의 미(美) 는 끊임없는 욕구이자 이상이 되어버렸다. 시대가 변할수록 점차 자신의 외모에 대한 관심이 많아지면서 외모관리가 경쟁력의 필 수요소가 되고 있으며(Min \& Kim, 2010), 성형수술에 대한 국민 의식의 변화는 더욱 적극적인 방향으로 발전하고 있다. 근래 들어 성에 따른 획일적 구분이 불분명해지면서, 여성들의 관심사였던 아 름다움의 추구는 자기표현의 수단으로써 남성뿐만 아니라 전 연령 층을 초월하여 확대되고 있다. 성형수술 또한 여성뿐만 아니라 남 성에 이르기까지 보편화되고 연령층이 다양해지고 있는 실정이다.
본래 성형수술은 상해 또는 선천적인 기형으로 인해 인체의 변 형과 미관상 보기 흉한 신체의 부분을 외과적인 교정 - 회복을 시 키는 수술을 의미하며(Kang, 1995), '재건성형(Plastic surgery)'과 '미용성형(Cosmetic surgery)'으로 나눌 수 있다. 재건성형수술은 선천성 - 후천성 기형이나 사고 - 재해 등의 사유로 망가지거나 없 어진 신체의 한 부분을 원상태로 복구하는 수술이라고 정의하고 (Kim, 2007), 미용성형수술은 위와 달리 병적인 원인이 아닌 정상 적인 상태를 가지고 태어났지만 신체적 조건을 더욱 아름답게 변 화하거나(Lee, 1998), 자신이 만족하지 못하는 외모를 더욱 만족 할 수 있는 수준으로 변모하기 위하여 행하여지는 수술을 의미한 다(Seo, 2007). 현재 우리나라는 미용을 목적으로 재건성형보다는 미용성형이 중점을 이루고 있다. 대한성형외과학회에 따르면 미 용성형수술의 종류는 크게 얼굴성형, 피부성형, 가슴성형, 체형보 정, 주름제거, 쁘띠성형 6가지 형태로 나눌 수 있다. 특히 얼굴성 형은 사람의 첫인상을 좌우하는데 결정적인 부분이라고 할 수 있 으며 미용성형수술에 있어서 가장 많이 행하여지는 부위이다. 
일반적으로 청소년기는 11-20세 사이의 시기를 일컨는데, 미용 성형은 보통 발육이 정지되는 18살 이상의 청소년기가 지난 사람 을 대상으로 한다(National Youth Policy Institute, 1996). 그 이유는 성장이 완료되지 않은 상태로 성형수술을 하게 되면 수술 한 부위가 국부적으로 성장 - 발육이 늦어지며 다른 부분과의 균 형이 맞지 않아 보기 흥한 결과가 나올 수도 있기 때문이다. 그러 나 부득이한 경우에는 성장 - 발육에 따라 몇 번이고 수술을 되풀 이하기도 한다. 아동기에서 성인기로 이행하는 과도기에 위치한 청소년기는(Song \& Kweon, 2014) 호로몬의 변화로 인한 급격한 성장 급등과 성적 성숙이 형성되는 시기로(Chung, 1998) 자신의 신체변화에 대해 인지하고 관심이 많아진다(Cheon et al., 2011). 또한 급격히 일어나는 변화와 발달에 대처할 수 있는 능력을 갖 추기에는 미숙하기 때문에 불안과 혼란 속에서 끊임없이 긴장하 고 갈등하게 된다(Lee \& Ahn, 2013). 특히 감수성이 풍부하고 외 모에 민감함 청소년들은 또래집단과 어울리는 시간이 많아지고 (Kim \& Kwon, 2014), 대중매체간의 사회적 상호작용이 증가함에 따라 끊임없이 정보를 수집하고 타인과 자신을 비교하는데 있어 서 이상적인 외모 기준에 미치지 못하면 스트레스를 받거나 좌절 하고(Kim \& Choi, 2012), 인정받고 싶은 심리적 의존성이 강하여 이를 극복하기 위해 여러 가지 형태의 외모관리 행동을 동반하기 도 한다(Kim \& Kim, 2002).

외모지상주의에 관한 기존연구들은 TV가 미용성형을 부추기는 주요한 요인임을 보여주었다(Shim, 2014). 버스나 지하철 등의 대 중교통을 이용하다 보면 성형외과의 광고를 쉽게 접할 수 있을 것 이다. 방송 프로그램인 '얼짱 시대'에서는 고등학생 얼짱들이 출 연하여 또래 집단들에게 많은 관심을 받았으며, 이로 인해 성형외 과의 홍보 모델이 되어 성형수술의 전 · 후를 자연스럽게 공개하 였다. 또한 연예인들도 마찬가지로 거리낌없이 대중매체에서 자 신의 성형 사실을 고백함으로써 대중들의 성형에 대한 인식의 변 화를 일으켰다. 법으로도 성형 수술에 대한 광고를 규제하고 있는 오늘, 직간접적으로 방송에서까지 성형수술을 권해야 하는지 의 문이다. 성형수술은 중 - 고등학생들도 쉽게 할 만큼 보편화 되었 는데 그만큼 부작용도 심각한 것으로 나타났다. 이에 따라 외모에 관심이 많은 중 - 고등학생들을 대상으로 성형수술에 대한 정확하 고 다양한 정보를 제공해야 할 필요성이 제기된다. Jeon \& Chung (2010)은 신체존중감에 따른 미용성형수술 경험의 차이는 신체존 중감이 높은 집단이 낮은 집단보다 미용성형수술을 더 많이 하는 것으로 파악되었다. 이에 본 연구는 성형수술에 대해 관심이 많은 고등학생 중에서 특성화 고등학교인 미용고등학교 학생들을 대상 으로 외모 만족도를 알아보고 미용성형에 대한 인식과 경험실태 를 조사하고, 그에 따른 부작용을 파악하고자 한다.

\section{Methods}

\section{1. 연구 대상 및 자료 수집}

본 연구는 충청지역의 미용고등학교 미용과 학생 492 명을 대상 으로 하였다. 조사기간은 2015년 8월 3일부터 2015년 9월 15일까 지 설문조사를 실시하였고, 설문지는 총 500 부를 배부하여 495 부 를 회수하였으며, 그 중 응답이 불충분한 설문지 3 부를 제외한 총 492부를 최종 분석 자료로 사용하였다.

\section{2. 연구 내용}

본 연구는 선행 연구를 참조하여 일반적인 특성 3 문항, 외모 만 족도 하위문항포함 8 문항, 미용성형의 인식 15 문항, 미용성형의 실태 하위문항포함 11 문항, 미용성형의 만족도와 부작용 하위문항 포함 12 문항 총 49 문항으로 설문지를 구성하였다.

\section{3. 자료 분석 방법}

수집된 자료는 부호화하여 SPSS ver. 21.0 (IBM, USA)로 통계 처리 하였다. 조사대상자의 일반적 특성에 따른 외모관련 요인, 미용성형의 필요성, 일반적 특성에 따른 부작용, 미용수술 후 변 한 점은 교차분석을 실시하였다. 또한 일반적 특성과 미용관련 특 성에 따른 미용성형 부위, 부작용 증상 그리고 성형수술 부위에 따른 미용성형 수술 후 변한 점에 대한 분석은 복수응답 처리하여 교차분석을 실시하였다. 본 연구의 분석에서 통계학적 신뢰수준 은 $95 \%$ 로 유의수준 $\alpha$ 는 0.05 로 하였다.

\section{Results and Discussion}

\section{1. 성별에 따른 외모관련 요인}

성별에 따른 외모관련 요인을 분석한 결과는 Table 1 과 같 다. 외모만족도는 남자와 여자 모두 '보통'이라는 응답이 $53.2 \%$ 와 $49.1 \%$ 로 가장 많았고, '매우 만족'이라는 응답에서는 남자가 $15.6 \%$ 인데 비해 여자는 $3.1 \%$ 로 가장 적은 것으로 나타났다. 기존 연구사례, Heo \& Cheon (2008)에서 남자보다 여자가 외모의 관 심도가 더 높은 것으로 나타났으며, 본 연구에서는 남자와 여자의 외모 중요성에 대한 결과로는 '중요하다'는 응답이 남자는 $40.4 \%$, 여자는 $46.7 \%$ 로 가장 높게 나타났고, '매우 중요하지 않다'에서는 남자가 $6.4 \%$, 여자가 $1.3 \%$ 로 가장 적은 응답을 보였다.

미용성형의향에서는 남자는 '전혀 그렇지 않다'가 $29.4 \%$ 로 가 장 많았고, '매우 그렇다가 $10.1 \%$ 로 가장 적었는데 여자는 '그렇 다'가 $41.0 \%$ 로 가장 많았고, '전혀 그렇지 않다'가 8.1\%로 남자와 유의한 차이를 보였다. Lee et al. (2006)은 대학 신입생들의 미 용성형의향을 연구한 결과 미용성형을 실시한 적은 없지만 원한 다는 응답이 $17.8 \%$ 였고, 미용성형을 하였거나 하고자 하는 응답 
이 $20.1 \%$ 로 이 중 여자가 $63.3 \%$ 로 남자보다 많은 것으로 나타났 으며, 이는 본 연구의 여자 고등학생과 유사한 결과를 보였다. 외 모 스트레스 경험에서는 남자의 경우 ‘없다'가 $55.0 \%$ 로 '있다'보다 높게 나타났으나 여자의 경우는 ‘있다'가 $72.1 \%$ 로 '없다'보다 훨씬 더 높게 나타났다.

\section{2. 일반적 특성에 따른 외모스트레스 해결방법}

외모스트레스를 받은 적이 있는 대상자들을 대상으로 일반 적 특성과 외모관련 특성에 따른 외모스트레스 해결방법을 분석 한 결과는 Table 2 와 같다. 외모에 대한 스트레스 해결방법은 남 자는 '기타'가 $36.5 \%$ 로 가장 많았고, 그 다음으로는 '헤어스타일

Table 1. Appearance factors by sex

Unit: $\mathrm{N}(\%)$

\begin{tabular}{|c|c|c|c|c|c|}
\hline \multirow{2}{*}{ Variable } & \multirow{2}{*}{ Item } & \multicolumn{2}{|c|}{ Sex } & \multirow{2}{*}{ Total } & \multirow{2}{*}{$p$-value } \\
\hline & & Male & Female & & \\
\hline \multirow{5}{*}{ Satisfaction with appearance } & Very satisfactory & $17(15.6)$ & $12(3.1)$ & $29(5.9)$ & \multirow[t]{5}{*}{0.000} \\
\hline & Satisfactory & $23(21.1)$ & $62(16.2)$ & $85(17.3)$ & \\
\hline & Average & $58(53.2)$ & $188(49.1)$ & $246(50.0)$ & \\
\hline & Unsatisfactory & $10(9.2)$ & $106(27.7)$ & $116(23.6)$ & \\
\hline & Very unsatisfactory & $1(0.9)$ & $15(3.9)$ & $16(3.3)$ & \\
\hline \multirow{5}{*}{ Importance of appearance } & Very important & $16(14.7)$ & 75 (19.6) & 91 (18.5) & \multirow[t]{5}{*}{0.016} \\
\hline & Important & $44(40.4)$ & $179(46.7)$ & $223(45.3)$ & \\
\hline & Average & $33(30.3)$ & $102(26.6)$ & $135(27.4)$ & \\
\hline & Unimportant & $9(8.3)$ & $22(5.7)$ & $31(6.3)$ & \\
\hline & Very unimportant & $7(6.4)$ & $5(1.3)$ & $12(2.4)$ & \\
\hline \multirow{5}{*}{ Intention of plastic surgery } & So yes & $11(10.1)$ & $72(18.8)$ & $83(16.9)$ & \multirow[t]{5}{*}{0.000} \\
\hline & Yes & $22(20.2)$ & $157(41.0)$ & $179(36.4)$ & \\
\hline & So so & $27(24.7)$ & $78(20.4)$ & 105 (21.3) & \\
\hline & No & $17(15.6)$ & $45(11.7)$ & $62(12.6)$ & \\
\hline & Never & $32(29.4)$ & $31(8.1)$ & $63(12.8)$ & \\
\hline \multirow{3}{*}{ Experience of appearance stress } & Yes & $49(45.0)$ & $276(72.1)$ & 325 (66.1) & \multirow[t]{2}{*}{0.000} \\
\hline & No & $60(55.0)$ & $107(27.9)$ & 167 (33.9) & \\
\hline & Total & 109 (100.0) & $383(100.0)$ & $492(100.0)$ & \\
\hline
\end{tabular}

Table 2. Methods of relieving appearance stress

Unit: $\mathrm{N}(\%)$

\begin{tabular}{|c|c|c|c|c|c|c|c|c|c|}
\hline \multirow[b]{2}{*}{ Variable } & \multirow[b]{2}{*}{ Item } & \multicolumn{6}{|c|}{ Methods of relieving appearance stress } & \multirow[b]{2}{*}{ Total } & \multirow[b]{2}{*}{$p$-value } \\
\hline & & Plastic surgery & Make up & Skin care & $\begin{array}{l}\text { Change } \\
\text { hair style }\end{array}$ & $\begin{array}{l}\text { Doing mask } \\
\text { pack at home }\end{array}$ & Etc. & & \\
\hline \multirow{2}{*}{ Sex } & Male & $9(17.3)$ & $4(7.7)$ & $4(7.7)$ & $14(26.9)$ & $2(3.8)$ & $19(36.5)$ & $52(100.0)$ & 0.000 \\
\hline & Female & $23(8.1)$ & $186(65.7)$ & $10(3.5)$ & $14(4.9)$ & $24(8.5)$ & $26(9.2)$ & $283(100.0)$ & \\
\hline \multicolumn{2}{|c|}{ Total } & $32(9.6)$ & $190(56.7)$ & $14(4.2)$ & $28(8.4)$ & $26(7.8)$ & $45(13.4)$ & $335(100.0)$ & \\
\hline
\end{tabular}

Table 3. Methods of raising money for plastic surgery

\begin{tabular}{|c|c|c|c|c|c|c|c|}
\hline \multirow{2}{*}{ Variable } & \multirow{2}{*}{ Item } & \multicolumn{4}{|c|}{ Methods of raising money for plastic surgery } & \multirow{2}{*}{ Total } & \multirow{2}{*}{$p$-value } \\
\hline & & Parents & Part time job & Pocket money & Etc. & & \\
\hline \multirow{2}{*}{ Sex } & Male & $5(41.7)$ & $4(33.3)$ & $1(8.3)$ & $2(16.7)$ & $12(100.0)$ & 0.234 \\
\hline & Female & $84(70.6)$ & $20(16.8)$ & $6(5.0)$ & $9(7.6)$ & $119(100.0)$ & \\
\hline \multirow{3}{*}{ Grade of high school } & 1st grade & $21(65.6)$ & $6(18.8)$ & $2(6.3)$ & $3(9.4)$ & $32(100.0)$ & 0.565 \\
\hline & 2nd grade & $16(88.9)$ & $2(11.1)$ & $0(0.0)$ & $0(0.0)$ & $18(100.0)$ & \\
\hline & 3rd grade & $52(64.2)$ & $16(19.8)$ & $5(6.2)$ & $8(9.9)$ & $81(100.0)$ & \\
\hline Total & & 89 (67.9) & $24(18.3)$ & $7(5.3)$ & $11(8.4)$ & $131(100.0)$ & \\
\hline
\end{tabular}


변화’가 $26.9 \%$ 로 나타났으며, 여자는 '화장'이 $65.7 \%$ 로 가장 많 이 나타났다. 고등학생들의 외모 스트레스 해결방법은 '화장'과 '헤어스타일 변화'가 가장 많다는 결과를 보였으며, $\mathrm{Kim} \& \mathrm{Kim}$ (2009)의 연구에서 성인들은 외모 스트레스를 해결하기 위해 화 장 - 미용성형수술 - 미용관리를 한다는 연구결과로, 학생과 성인 이라는 신분의 차이로 인한 금전적인 부분에 영향을 미치는 것으 로 보이며 본 연구와 유의한 차이가 있었다.

\section{3. 미용성형수술 경험자들의 성형비용 마련방법}

미용성형 수술 경험이 있는 대상자의 일반적 특성과 외모 관 련 특성에 따른 성형비용 마련방법을 분석한 결과는 Table 3 과 같 으며 '부모님'이 $67.9 \%$ 로 가장 많았고, '아르바이트' $18.3 \%$, '기타' $8.4 \%$ 순이었으며, '용돈'이 $5.3 \%$ 로 가장 적게 나타났다.

\section{4. 성별에 따른 미용성형부위(복수응답)}

성별에 따른 미용성형부위를 복수응답으로 처리하여 분석 한 결과는 Table 4 와 같다. 눈 성형의 경우 남자는 '쌍꺼풀'이
90.0\%로 가장 많았고, '앞 - 뒤밑트임'과 '시력교정(라식, 라섹)' 이 각각 $10.0 \%$ 로 나타났으며 여자는 '쌍꺼풀'이 $96.3 \%$ 로 가장 많았고, '앞 - 뒤밑트임'이 $32.1 \%$, '아이라인과 눈썹문신'이 $3.7 \%$ 에 이어, '눈밑애교필러'와 '시력교정(라식, 라섹)'은 $1.8 \%$ 로 가장 적었다. 코 성형의 경우 남자는 '콧대높힘'이라는 응답이 $100.0 \%$ 인데 비해 여자의 경우는 '콧대높힘'이 $47.1 \%$ 로 가장 많았고, '코 필러' $29.4 \%$, '콧볼축소' $23.5 \%$, '코끝' $11.8 \%$ 의 순이었으며, '매 부리수술'이 $5.9 \%$ 로 가장 적었다. 입 성형에서는 남자의 경우 '치아교정 및 미백'이 $100.0 \%$ 인데 비해 여자는 '치아교정 및 미 백'이 $85.7 \%$ 로 가장 많았고, '입꼬리'와 '입술필러'가 각각 $14.3 \%$ 로 나타났다.

\section{5. 일반적 특성에 따른 성형수술 후 변한 점}

일반적 특성에 따른 성형수술 후 변한 점을 복수응답 처리하 여 분석한 결과는 Table 5 와 같다. 미용성형 수술 후 변한 점은 $1,2,3$ 학년 모두 ‘자기만족 및 자신감 상승'이 가장 많았고, 그밖에 '이미지 상승 및 원만한 대인관계', '기대 이하의 수술 결과로 인한

Table 4. The operated area of plastic surgery by sex (multiple responses)

Unit: N (\%)

\begin{tabular}{|c|c|c|c|c|}
\hline \multirow{2}{*}{ Variable } & \multirow{2}{*}{ Item } & \multicolumn{2}{|c|}{ Sex } & \multirow{2}{*}{ Total } \\
\hline & & Male & Female & \\
\hline \multirow{5}{*}{ Eyes surgery } & Double eyelid & $9(90.0)$ & $105(96.3)$ & $114(95.8)$ \\
\hline & Eyes expansion & $1(10.0)$ & $34(32.1)$ & $35(29.4)$ \\
\hline & Eyes filler & $0(0.0)$ & $2(1.8)$ & $2(1.7)$ \\
\hline & Eye line, Eyebrow tattoo & $0(0.0)$ & $4(3.7)$ & $4(3.4)$ \\
\hline & Vision correction & $1(10.0)$ & $2(1.8)$ & $3(2.5)$ \\
\hline \multirow{5}{*}{ Nose surgery } & Raising the nasal bridge & $1(100.0)$ & $8(47.1)$ & $9(50.0)$ \\
\hline & Nasal tip & $0(0.0)$ & $2(11.8)$ & $2(11.1)$ \\
\hline & Nostrils reduction surgery & $0(0.0)$ & $4(23.5)$ & $4(22.2)$ \\
\hline & Nose filler & $0(0.0)$ & $5(29.4)$ & $5(27.8)$ \\
\hline & Hooked nose surgery & $0(0.0)$ & $1(5.9)$ & $1(5.6)$ \\
\hline \multirow{3}{*}{ Lips surgery } & Lips tail surgery & $0(0.0)$ & $2(14.3)$ & $2(12.5)$ \\
\hline & Orthodontic treatment & $2(100.0)$ & $12(85.7)$ & $14(87.5)$ \\
\hline & Lips filler & $0(0.0)$ & $2(14.3)$ & $2(12.5)$ \\
\hline
\end{tabular}

Table 5. Changes after undergoing plastic surgery (multiple responses)

Unit: $\mathrm{N}(\%)$

\begin{tabular}{|c|c|c|c|c|c|c|c|}
\hline \multirow[b]{2}{*}{ Variable } & \multirow[b]{2}{*}{ Item } & \multicolumn{4}{|c|}{ Changes after undergoing plastic surgery } & \multirow[b]{2}{*}{ Total } & \multirow[b]{2}{*}{$p$-value } \\
\hline & & $\begin{array}{l}\text { Increase of self- } \\
\text { satisfaction and } \\
\text { confidence }\end{array}$ & $\begin{array}{l}\text { Better facial image } \\
\text { and interpersonal } \\
\text { relationship }\end{array}$ & $\begin{array}{l}\text { Loss of } \\
\text { confidence due } \\
\text { to wrong result }\end{array}$ & Etc. & & \\
\hline \multirow{2}{*}{ Sex } & Male & $4(33.3)$ & $3(25.0)$ & $4(33.3)$ & $1(8.3)$ & $12(100.0)$ & \multirow[t]{2}{*}{0.068} \\
\hline & Female & $58(48.7)$ & 37 (31.1) & $10(8.4)$ & $14(11.8)$ & $119(100.0)$ & \\
\hline \multirow{3}{*}{$\begin{array}{l}\text { Grade } \\
\text { of high } \\
\text { school }\end{array}$} & 1st grade & $20(62.5)$ & 7 (21.9) & $4(12.5)$ & $1(3.1)$ & $32(100.0)$ & \multirow[t]{3}{*}{0.047} \\
\hline & 2nd grade & $8(44.4)$ & 7 (38.9) & $3(16.7)$ & $0(0.0)$ & $18(100.0)$ & \\
\hline & 3rd grade & $34(42.0)$ & $26(32.1)$ & $7(8.6)$ & $14(17.3)$ & $81(100.0)$ & \\
\hline
\end{tabular}


자신감 감소, '기타' 순으로 나타났다. Lee et al. (2006)의 연구에 서 대학 신입생들의 성형 수술 후 자신의 외모에 대한 만족도(3.6

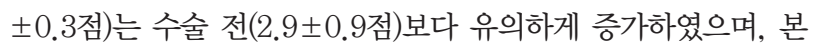
연구와 유사한 결과를 보였고 이는 연령대와 상관없이 학생, 성인 모두가 미용성형수술 후 '자기만족 및 자신감'이 상승했다는 것을 볼 수 있었다.

\section{6. 미용성형 경험자들의 미용성형 재수술 의향의 이유}

일반적 특성과 성형관련특성에 따른 추가미용성형을 더 받고 싶은 이유를 분석한 결과는 Table 6과 같다. 성형만족도의 경우 모든 집단에서 '외모에 자신감이 생겨서'라고 응답한 경우가 가장 많았는데 그 중 '매우 만족'이 $75.0 \%$ 로 가장 많았고, '만족'에서는 $62.5 \%$, '보통'
은 56.3\%, '불만족'은 $53.3 \%$ 의 순이었으며 '매우 불만족'은 $50.0 \%$ 로 가 장 적었다. '대인관계와 사회생활에 도움'이라고 응답한 경우는 '매우 불만족'에서 $50.0 \%$ 로 가장 많았고, '매우 만족'은 25.0\%, 만족'은 6.3\% 였다. 만족하지 못해서'라는 응답은 '불만족'에서 $33.3 \%$ 로 가장 많았 고, '보통'은 3.1\%였다. '다른 부분도 하고 싶어서'라는 응답은 '보통'에 서 $40.6 \%$ 로 가장 많았고, 만족'은 $31.3 \%$, '불만족'은 $13.3 \%$ 로 나타났 다. 반면에 성별, 학년, 성형계기에서도 추가 미용성형을 더 받고 싶 은 이유가 '외모에 자신감이 생겨서'라는 응답이 가장 높게 나타났다.

\section{7. 성별에 따른 미용성형 부작용 증상}

성별에 따른 미용성형 부작용 증상을 복수응답 처리한 분석 결과는 Table 7과 같다. 부작용 증상은 남자의 경우 '멍, 붓기'가

Table 6. Reasons of reoperation intention

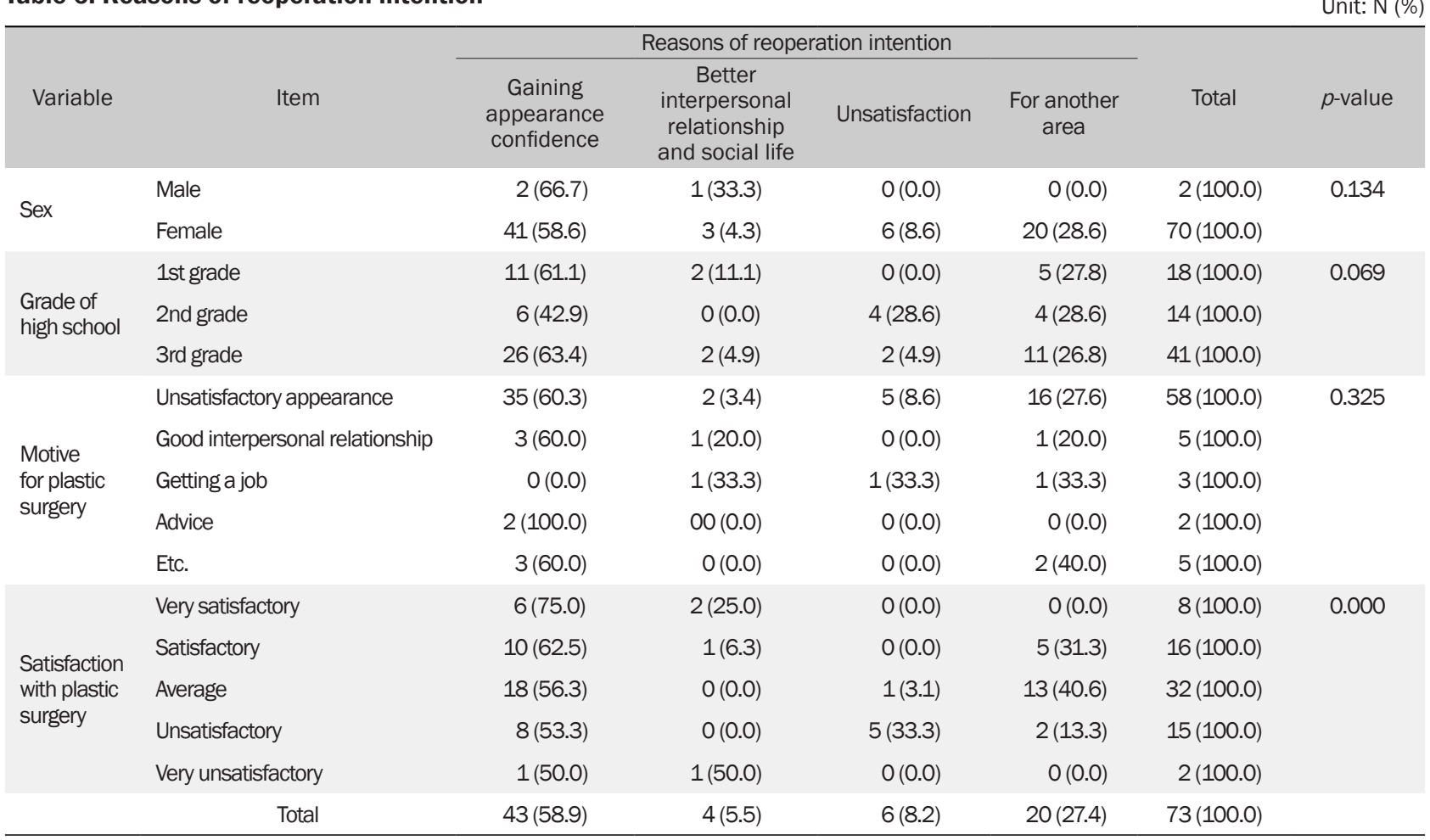

Table 7. Side effects of plastic surgery by sex (multiple responses)

Unit: $N(\%)$

\begin{tabular}{|c|c|c|c|c|c|}
\hline \multirow{2}{*}{ Variable } & \multirow{2}{*}{ Item } & \multicolumn{2}{|c|}{ Sex } & \multirow{2}{*}{ Total } & \multirow{2}{*}{$p$-value } \\
\hline & & Male & Female & & \\
\hline \multirow{7}{*}{ Side effect } & Bruise, Swelling & $3(50.0)$ & 39 (69.6) & $42(67.7)$ & - \\
\hline & Inflammation & $0(0.0)$ & $4(7.1)$ & $4(6.5)$ & \\
\hline & Incorrect ratio & $2(33.3)$ & 24 (42.9) & 26 (41.9) & \\
\hline & Continuous pain & $0(0.0)$ & $7(12.5)$ & $7(11.3)$ & \\
\hline & Red marks & $2(33.3)$ & $7(12.5)$ & $9(14.5)$ & \\
\hline & Etc. & $0(0.0)$ & $5(8.9)$ & $5(8.1)$ & \\
\hline & Total & $7(9.7)$ & $86(90.3)$ & $93(100.0)$ & \\
\hline
\end{tabular}


$50.0 \%$ 로 가장 많았고, '잘못된 비율'과 '붉은 자국'이 각각 $33.3 \%$ 였다. 여자의 경우에서도 '멍, 붓기'가 $69.6 \%$ 로 가장 많았고, '잘못 된 비율'은 $42.9 \%$, '지속적 통증'과 '붉은 자국'은 각각 $12.5 \%$ 였으 며, '염증'은 $7.1 \%$, '기타'가 8.9\%이었다.

\section{Conclusion}

본 연구는 외모, 성형수술에 대한 관심이 많은 고등학생 중에서도 미용과 연관된 특성화 고등학교인 미용고등학교 학생들을 대상으로 외모의 만족도를 알아보고 미용성형에 대한 인식과 경험실태를 조 사하여 그에 따른 부작용을 연구한 것으로 결과는 다음과 같다.

성별에 따른 외모 관련요인은 남자가 여자보다 외모에 대해 매 우 만족하였고, 여자가 남자보다 외모를 매우 중요시 여겼으며, 외모스트레스 경험과 미용성형을 할 의향이 훨씬 많았다. 외모 스 트레스 경험에서 남녀 모두 성형경험이 있는 경우가 없는 경우보 다 더 많았고, 남자는 헤어스타일 변화, 여자는 화장을 함으로써 스트레스를 해결하였다. 미용성형부위의 복수응답으로는 남녀 모 두 쌍꺼풀, 콧대높임, 치아교정 및 미백이 많은 응답을 보였다. 성 형수술 후 추가미용성형 의향이 있는 경우는 여자가 남자보다 더 많았으며 재수술 의향의 이유는 외모에 자신감이 생겼기 때문이 었다. 미용성형 부작용 증상으로는 남자와 여자 모두 멍, 붓기가 가장 많았다.

이와 같은 연구 결과에 따르면 고등학생들은 외모에 대한 스트레 스를 경험함으로써 성형을 하는 경우가 많고, 외모를 중요시 여김 으로써 미용성형의향이 높은 것으로 나타나 성형에 거리낌이 없다 는 것을 볼 수 있었다. 하지만 청소년기는 육체적으로 완전히 성숙 되지 않고 성장하는 시기라 부작용을 경험한 응답자가 많았다. 따 라서 본 연구는 청소년들이 호기심에 이끌려 섣불리 성형수술을 계 획하기 전에 한 번 더 생각하고 선택할 수 있는 계기가 되는 자료로 활용되어야 할 것이다. 향후 조사지역을 넓혀 광범위한 지역을 바 탕으로 대상을 세분화한 연구가 지속적으로 이루어지길 기대한다.

This work is part of the Eun Hee Jo's M.S. thesis at the Daejeon University, Daejeon, Korea.

\section{References}

Cheon JU, Kim M, Kim JH, Park SY. Introduction to youth studies. Yangseowon Publishing, Paju, pp22-27, 2011.

Chung OB. Adolescence: an introduction. Hakjisa, Seoul, pp97-119, 1998.
Heo SY, Cheon HM. Interest in the appearances, cosmetic surgery and skin care practice by the high school and college students. Journal of Investigative Cosmetology, 4: 183-190, 2008.

Jeon HJ, Chung MS. The effects fo socilcultural attitudes toward appearance and body esteem on cosmetic surgeries. Journal of the Korean Society of Cosmetology, 16: 734-741, 2010.

Kang JS. Plastic surgery. Keimyung University Press, Daegu, pp15-17, 1995.

Kim HJ, Kwon HJ. A study on behavior petten of purchase and usage of cosmetic according to interest in appearance of adolescents. Asian Journal of Beauty and Cosmetology, 12: 353-359, 2014.

Kim JA, Kim YS. A study on the body cathexis and appearance management behaviors of high school girls. Journal of Korean Home Economics Education Association, 14: 55-73, 2002.

Kim SH, Kim SK. A study on the behavior of cosmetic surgery of working women in their 20s-30s according to the degree of importance of outward appearance. Journal of the Korean Society of Beauty and Art, 10: 5-15, 2009.

Kim YH, Choi YJ. Korean youth who they are. Jungmin Publishing, Paju, pp15-70, 2012.

Kim YJ. Effects of aesthetic surgery on body image, selfesteem and satisfaction with outcomes. Journal of the Korean Society of Cosmetology, 13: 1236-1246, 2007.

Kim YR, Nam MW. The effect of female universities student's beauty care on the stress. Asian Journal of Beauty and Cosmetology, 8: 263-273, 2010.

Lee K, Lim HS, Chang KS. Status of perceptions for appearance and cosmetic surgery among university freshmen. The Dongguk Journal of Medicine, 13: $27-$ 36, 2006.

Lee KH, Ahn GYR. The effect of the interest and satisfaction in appearance on interpersonal relations and selfesteem. The Journal of the Korean Association of Psychotherapy, 5: 73-83, 2013.

Lee YH. Aesthetic plastic surgery. Koonja Publishing, Seoul, pp63-150, 1998.

Min JY, Kim HJ. The effect of manual lymph drainage on the reduction of stress and edema after facial 
aesthetic plastic surgery. Asian Journal of Beauty and Cosmetology, 8: 143-156, 2010.

National Youth Policy Institute. Adolescent psychology. Seowon, Seoul, pp19-31, 1996.

Seo JH. Aesthetic surgery attitude and needs types of the adolescent consumers: in Ulsan metropolitan city. Journal of the Korean Data Analysis Society, 9: 22112222, 2007.
Shim JW. Effects of TV entertainment program exposure on adolescents' willingness to take cosmetic surgery: the role of benevolent sexism. Korean Journal of Sexual Health, 1: 87-98, 2014.

Song SM, Kweon SY. Causal relations among appearance satisfaction, self-efficacy, and school adaptation of adolescents. Journal of Future Oriented Youth Society, 11: 93-115, 2014. 


\section{국문초록}

\section{미용고등학교 학생들의 미용성형에 대한 인식 및 경험실태에 관한 연구}

조은희 ${ }^{1}$, 이명선 $2^{*}$

${ }^{1}$ 대전대학교 보건의료대학원 미용의학과, 대전, 한국

${ }^{2}$ 대전대학교 뷰티건강관리학과, 대전, 한국

목적: 본 연구는 미용고등학교 학생들의 외모의 만족도를 알아보고 미용성형에 대한 인식과 경험실태를 조사하여 그에 따른 부작용을 파악하고자 하였다. 방법: 충청지역의 미용고등학교 미용과 학생 492 명을 대상으로 설문조사를 하였고 수집된 자료 는 SPSS ver. 21.0 프로그램을 이용하였으며 복수응답처리 후 교차분석을 실시하였다. 결과: 외모 스트레스 경험이 있는 경우 는 남자보다 여자가 훨씬 많았고, 성형 경험이 있는 경우는 남자보다 여자가 더 많은 것으로 나타났다. 미용성형 수술 후 부작 용을 경험했다는 응답자가 $45.8 \%$ 였으며 증상으로는 멍, 붓기가 가장 많았다. 결론: 이와 같은 연구 결과에 따르면 고등학생들 은 외모에 대한 스트레스를 경험함으로써 성형을 하는 경우가 많았고, 미용성형 수술 후 변한 점으로는 자기만족 및 자신감 상 승이 가장 높게 나타났다. 하지만 완전히 성숙되지 않고 성장하는 시기라 부작용을 경험한 응답자가 많았다.

핵심어: 미용성형, 미용고등학교, 학생, 인식, 경험

\section{참고문헌}

강진성. 최신 성형외과학. 계명대학교 출판부, 대구, $\mathrm{pp} 15-17,1995$.

김성희, 김순구. 20 - 30 대 직장여성의 외모 중요도에 따른 미용성형행동 연구. 한국인체미용예술학회지, $10: 5-15,2009$. 김영란, 남미우. 여대생의 미용관심 요인이 스트레스에 미치는 영향. 아시안뷰티화장품학술지, 8: 263-273, 2010. 김영주. 미용체형 성형수술 후 신체상과 자기존중감 및 만족도 변화연구. 한국미용학회지, 13: 1236-1246, 2007. 김영화, 최영진. 오늘의 청소년, 그들은 누구인가?: 청소년복지론. 정민사, 파주, $\mathrm{pp} 15-70,2012$.

김정애, 김용숙. 여고생의 신체만족도와 외모관리행동에 관한 연구. 한국가정과교육학회지, $14: 55-73,2002$.

김희자, 권혜진. 청소년의 외모관심도에 따른 화장품 사용실태와 구매행태 연구. 아시안뷰티화장품학술지, 12: 353-359, 2014. 민자영, 감형주. 엠엘디(MLD)가 안면성형수술 후 스트레스, 부종 감소에 미치는 영향. 아시안뷰티화장품학술지, 8: 143-156, 2010. 서정희. 청소년소비자의 성형수술에 대한 태도와 요구의 유형: 울산광역시를 중심으로. 한국자료분석학회지, 9: 2211-2222, 2007. 송선미, 권순용. 청소년의 외모만족도가 학교적응에 미치는 영향과 자기효능감의 매개효과. 미래청소년학회지, 11: 93-115, 2014. 심재웅. TV예능 · 오락프로그램 시청이 청소년들의 미용성형수술 의지에 미치는 영향: 온정적 성차별주의의 역할. 대한

성학회지, 1: $87-98,2014$.

이경희, 안귀여루. 청소년의 외모관심과 외모만족도가 대인관계와자아존중감에 미치는 영향. 한국심리치료학회지, 5: 73-83, 2013. 이관, 임현술, 장경순. 대학 신입생의 외모에 대한 인식 및 미용성형 수술 실태. 동국의학, 13: 27-36, 2006. 이윤호. 미용성형외과학. 군자출판사, 서울, pp63-150, 1998.

전현진, 정명선. 외모에 대한 사회문화적 태도와 신체존중감이 미용성형수술에 미치는 영향. 한국미용학회지, 16: 734- 741, 2010. 정옥분. 청년발달의 이해. 학지사, 서울, $\mathrm{pp} 97-119,1998$.

천정웅, 김민, 김진호, 박선영. 차세대 청소년학총론. 양서원, 파주, $\mathrm{pp} 22-27,2011$.

한국청소년정책연구원. 청소년심리학. 서원, 서울, $\mathrm{pp} 19-31,1996$.

허선영, 전혜민. 고등학생과 대학생의 외모 및 미용성형 관심도와 피부관리 실천행위. 대한미용학회지, 4: 183-190, 2008. 


\section{中文摘要}

\section{美容高校学生对美容整形的认识与经验现状调查}

曺殷姬，李明宣 ${ }^{2 *}$

${ }^{1}$ 大田大學校 保健醫療大學院 美容医学科, 大田, 韩国

${ }^{2}$ 大田大學校 Beauty健康管理學科, 大田, 韩国

目的：调查美容高校学生对外貌的满意度, 美容整形的认识, 经验现状以及整形的副作用。方法: 对忠清地区的美容 高等学校美容科学生492名进行问卷调查, 其调查资料利用 SPSS ver 21.0分析, 并复数应答处理后, 进行交叉分析。 结果: 调查结果显示, 女人比男人对外貌更具有压力, 女人比男人具有更多整形经历。整形手术之后, 产生副作用的 占 $45.8 \%$, 其症状主要为挫伤和肿胀。结论: 通过以上研究高校学生大部分对外貌产生压力, 因此实施整形的人数较 多。美容整形手术之后, 主要改善的情况为自我满足和自信感提升。但是高校学生仍处于成长阶段, 还没有发育完 全，所以产生副作用的应答者也很多。

关键词: 美容整形, 美容高等学校, 学生, 认识, 经验 
